\title{
INFLUENCE OF SILICA FUME ADDITION ON SELECTED PROPERTIES OF FINE-GRAINED CONCRETE
}

\author{
Arkadiusz DENISIEWICZ1 ${ }^{1}$ Krzysztof KULA, Tomasz SOCHA, \\ Grzegorz KWIATKOWSKI \\ University of Zielona Gora, Poland
}

\begin{abstract}
The article presents the results of laboratory tests of selected mechanical and physical properties of fine-grained concrete. The tests were carried out on samples with varying degrees of microsilica addition. The consistency class, shrinkage, compressive and bending strength, water resistance and frost resistance were determined for the designed concrete mixtures and made samples.
\end{abstract}

Keywords: $\quad$ silica fume, fine-grained concrete, laboratory tests

\section{INTRODUCTION}

Silica fume, otherwise known as microsilica, is waste produced in the production of iron-silicon alloys and has strong pozzolanic properties. It consists mainly of spherical granules of amorphous silicon dioxide $\mathrm{SiO}_{2}$, which content ranges from $87 \div 98 \%$. The use of microsilica has a positive effect on the porosity of concrete (lowering it), water permeability, reduces swelling and increases the strength. The positive effect of silica fume on the mechanical properties of concrete is the effect of increasing the adhesion of the grout to the aggregate

\footnotetext{
${ }^{1}$ Corresponding author: University of Zielona Gora, Faculty of Building, Architecture and Environmental Engineering, Z. Szafrana st 1, 65-516 Zielona Góra, Poland, e-mail: a.denisiewicz@ib.uz.zgora.pl, tel. +48683282271
} 
grains and reducing the porosity of the transition zone. This is due to the cooperation of microsilica with superplasticizers and its pozzolanic activity [2]. Silica fume is an essential addition to ultra-high-strength concrete such as reactive powder concrete (RPC) [1,3,4]. It is fine-grained concrete in which the most important factor causing high strength is a large reduction in crack formation caused by, for example, load or shrinkage, by reducing the maximum grain size aggregate $\leq 600 \mu \mathrm{m}$ and degrading them to micro. Table 1 shows an example of a recipe for such a concrete.

Table 1. An example of RPC concrete composition

\begin{tabular}{|c|c|c|}
\hline Component & Volume $\left[\mathrm{kg} / \mathrm{m}^{3}\right]$ & Mass percentage [\%] \\
\hline Cement & 705 & 28.20 \\
\hline Silica fume & 230 & 9.20 \\
\hline Crushed quartz $\leq 200 \mu \mathrm{m}$ & 210 & 8.40 \\
\hline Sand $\leq 600 \mu \mathrm{m}$ & 1013 & 40.52 \\
\hline Superplasticizer & 17 & 0.68 \\
\hline Steel fibers & 140 & 5.60 \\
\hline Water & 185 & 7.40 \\
\hline
\end{tabular}

The main task of this work is to examine the effect of the addition of microsilica on selected properties of fine-grained concrete in order to later use observed regularities for RPC design. The recipe was limited only to the necessary ingredients (cement, aggregate, microsilica, water) to avoid the influence of other components on the properties of the mixture and finished concrete.

\section{MIXTURE RECIPES AND SAMPLES}

Three cubes of $15 \times 15 \times 15 \mathrm{~cm}, 3$ cubes $10 \times 10 \times 10 \mathrm{~cm}$ and 3 rectangular bars 10x10x50 cm with 5 concrete mixtures (Table 2) with different microsilica content were prepared for laboratory tests. A total of 45 samples. Concrete cement was made of CEM I $32.5 \mathrm{R}$ cement from Górażdże cement plant, SILIMIC U silica fume in non-compressed form with bulk density up to $350 \mathrm{~kg} / \mathrm{m}^{3}$ and OS 36 fraction from $0.063-0.315 \mathrm{~mm}$ fraction from Osiecznica mine. The tightness equation was fulfilled for accepted formulas.

$$
\frac{C}{\rho_{C}}+\frac{P k}{\rho_{P k}}+\frac{W}{\rho_{W}}+\frac{P}{\rho_{p}}=1
$$

Compressive strength was estimated based on the following relationship [11].

$$
\left.f_{\sigma}=\frac{188,4}{21,7\left(\frac{W}{C+P k}-0,15^{p k}\right.}\right)
$$


where:

$\mathrm{C}, \mathrm{Pk}, \mathrm{W}, \mathrm{P}$ - quantity $\left[\mathrm{kg} / \mathrm{m}^{3}\right]$ : cement, silica fume, water, sand; $\rho_{\mathrm{c}}, \rho_{\mathrm{Pk}}, \rho_{\mathrm{w}}, \rho_{\mathrm{p}}-$ density $\left[\mathrm{kg} / \mathrm{m}^{3}\right]$ : cement, silica fume, water, sand; $\mathrm{f}_{\mathrm{c}}$ - theoretical compressive strength.

After the samples were made, they were seasoned for 28 days in the thermalhumid conditions as in Figure 1. For the first 48 hours, the samples were stored under constant thermal and humid conditions in accordance with PN-EN 12390-2:2011 [6].

Table 2. Designed concrete mix recipes

\begin{tabular}{|l|c|c|c|c|c|}
\hline \multirow{2}{*}{ Parameter } & \multicolumn{5}{c|}{ Percentage content silica fume } \\
\cline { 2 - 6 } & $0 \%$ & $5 \%$ & $10 \%$ & $15 \%$ & $20 \%$ \\
\hline Determination of the mixture & I & II & III & IV & V \\
\hline Cement $\left[\mathrm{kg} / \mathrm{m}^{3}\right]$ & 600 & 600 & 600 & 600 & 600 \\
\hline Silica fume $\left[\mathrm{kg} / \mathrm{m}^{3}\right]$ & 0 & 32.5 & 65 & 97.5 & 130 \\
\hline Sand OS $36\left[\mathrm{~kg} / \mathrm{m}^{3}\right]$ & 820 & 780 & 740 & 700 & 660 \\
\hline Water & 485 & 485 & 485 & 485 & 485 \\
\hline W/C & 0.75 & 0.75 & 0.75 & 0.75 & 0.75 \\
\hline W/S & 0.75 & 0.71 & 0.68 & 0.65 & 0.62 \\
\hline Volume $\left[\mathrm{kg} / \mathrm{m}^{3}\right]$ & 1955 & 1947.5 & 1940 & 1932.5 & 1925 \\
\hline The tightness equation & 1.0 & 1.0 & 1.0 & 1.0 & 1.0 \\
\hline $\begin{array}{l}\text { Theoretical compressive strength } \\
{[\mathrm{MPa}]}\end{array}$ & 18.96 & 21.65 & 27.47 & 27.42 & 30.49 \\
\hline
\end{tabular}

\section{RESULTS OF THE LABORATORY TESTS}

\subsection{Consistency testing}

Testing the consistency of designed concrete mixtures was carried out with the use of a drop cone method in accordance with PN-EN 12350-2: 2011 [5]. The obtained results are presented in Table 3.

Table 3. The results of testing the consistency of designed mixtures

\begin{tabular}{|c|c|c|c|c|}
\hline $\begin{array}{c}\text { Determination } \\
\text { of the mixture }\end{array}$ & Silica fume [\%] & Drop cone [mm] & \multicolumn{2}{|c|}{ Consistency class } \\
\hline I & 0 & 200 & Semi liquid & K4 \\
\hline II & 5 & 160 & Semi liquid & K4 \\
\hline III & 10 & 130 & Plastic & K3 \\
\hline IV & 15 & 110 & Plastic & K3 \\
\hline V & 20 & 90 & Dense plastic & K2 \\
\hline
\end{tabular}


The results of the study are in line with expectations. Together with the increase in the amount of microsilica added to the concrete mixture, its density increases, which is the effect of the decreasing W/S water and binder ratio.

\subsection{Contraction test}

The contraction test was carried out on $10 \times 10 \times 50 \mathrm{~cm}$ rectangular bars using the Amsler apparatus. The first measurement of shrinkage was made after 48 hours of the samples being made. Samples from the moment of execution from the first measurement were stored in constant thermal and humid conditions in accordance with PN-EN 12390-2: 2011 [6]. After 48 hours, samples were stored at an average temperature of $21^{\circ} \mathrm{C}$, and average air humidity: $36.8 \%$. The exact distribution of temperature and air humidity during the 28-day seasoning of samples is shown in the graph in Figure 1. Figure 2 shows the course of average time shrinkage for beams made of individual mixtures (Table 2). Three bars made of each mix were used for the study. The results were averaged. On the basis of the obtained results, it is possible to confirm the positive effect of the addition of microsilica (in the tested range) on the shrinkage of the tested samples. As the amount of silica fume increases, the speed of shrinkage decreases in the mix, which limits the cracking of the finished concrete.

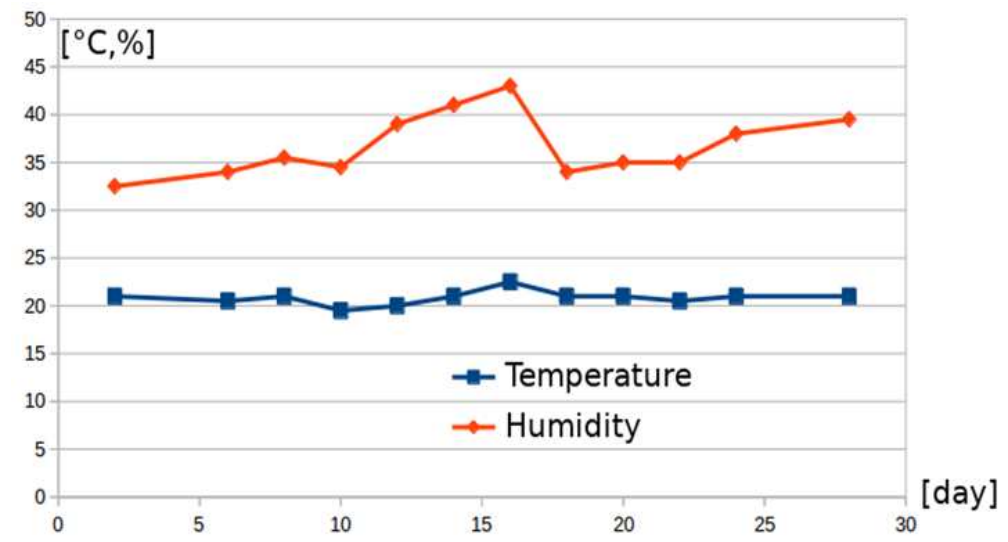

Fig. 1. Distribution of temperature and air humidity during the contraction test 


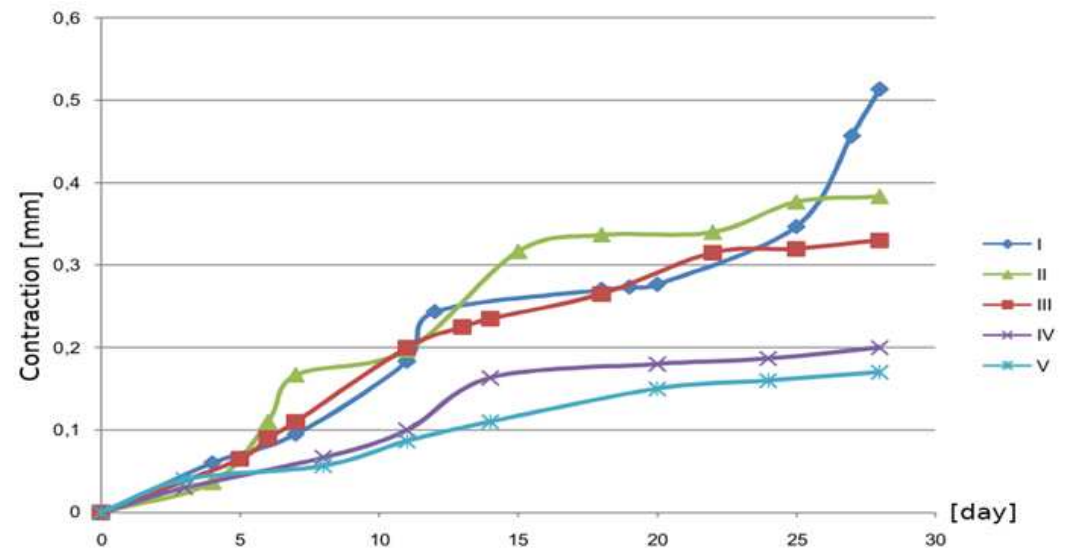

Fig. 2. Medium shrinkage of beams made of individual mixtures

\subsection{Compressive strength test}

The compressive strength test comprised cubic samples with a side of $15 \mathrm{~cm}$. Each of the samples ripened at least 28. The study was carried out in accordance with PN-EN 12390-3:2011 [7]. Strength classes of the tested concrete were determined on the basis of PN-EN 206-1:2003 [10].

Table 4. The results of the compressive strength test

\begin{tabular}{|c|c|c|c|c|c|}
\hline $\begin{array}{c}\text { Sample } \\
\text { mark }\end{array}$ & $P_{c}[k N]$ & $\mathrm{f}_{\mathrm{c}, 28}[\mathrm{MPa}]$ & $\mathrm{P}_{\mathrm{cm}}[\mathrm{kN}]$ & $\mathrm{f}_{\mathrm{cm}, 28}[\mathrm{MPa}]$ & Class of concrete \\
\hline G I 1 & 856.6 & 38.07 & \multirow{3}{*}{736.5} & \multirow{3}{*}{32.73} & \multirow{3}{*}{$\mathrm{C} 16 / 20$} \\
\hline G I 2 & 767.5 & 34.11 & & & \\
\hline G I 3 & 585.5 & 26.02 & & & \\
\hline G II 1 & 824.6 & 36.65 & \multirow{3}{*}{803.7} & \multirow{3}{*}{35.72} & \multirow{3}{*}{$\mathrm{C} 25 / 30$} \\
\hline G II 2 & 857.7 & 38.12 & & & \\
\hline G II 3 & $\begin{array}{l}728.8 \\
\end{array}$ & 32.39 & & & \\
\hline G III 1 & 886.5 & 39.40 & \multirow{3}{*}{897.4} & \multirow{3}{*}{39.88} & \multirow{3}{*}{ C30/37 } \\
\hline G III 2 & 966.8 & 42.97 & & & \\
\hline G III 3 & 838.8 & 37.28 & & & \\
\hline G IV 1 & 914.2 & 40.63 & \multirow{3}{*}{926.9} & \multirow{3}{*}{41.20} & \multirow{3}{*}{$\mathrm{C} 30 / 37$} \\
\hline G IV 2 & 875.5 & 38.91 & & & \\
\hline G IV 3 & 991.1 & 44.05 & & & \\
\hline G V 1 & 1037.5 & 46.11 & \multirow{3}{*}{964.2} & \multirow{3}{*}{42.85} & \multirow{3}{*}{ C30/37 } \\
\hline G V 2 & 997.2 & 44.32 & & & \\
\hline G V 3 & 857.9 & 38.13 & & & \\
\hline
\end{tabular}


where $P_{c}$ - destructive force of the sample, $f_{c}, 28$ - compressive strength of concrete after 28 days calculated from the formula:

$$
f_{c, 29}=\frac{P_{c}}{A}
$$

A - cross-sectional area of the sample $225 \mathrm{~cm}^{2}, \mathrm{P}_{\mathrm{cm}}$ - average destructive force of the sample, $\mathrm{f}_{\mathrm{cm}}, 28$ - average compressive strength of concrete after 28 days.

In the studied range, the results confirm the positive effect of the addition of microsilica on the compressive strength of concrete. At the same time, it should be noted that in the tested mixtures the formula (2.2) underestimates the real strength by an average of $55 \%$. With the increase in the amount of silica fume in the mix, the underestimation of the compressive strength is lower.

\subsection{Bending strength test}

The bending strength test was carried out on rectangular bars $10 \times 10 \times 50 \mathrm{~cm}$, according to PN-EN 12390-5:2011 [8]. Samples were tested during the threepoint bending test, figure 3 .

Table 5. The results of the bending strength test

\begin{tabular}{|c|c|c|c|}
\hline Sample mark & $\mathrm{F}[\mathrm{kN}]$ & $\begin{array}{l}\text { Average damage } \\
\text { force }[\mathrm{kN}]\end{array}$ & $\mathrm{f}_{\mathrm{cf}}[\mathrm{MPa}]$ \\
\hline G I 1 & 3.94 & \multirow{3}{*}{3.49} & \multirow{3}{*}{1.57} \\
\hline G I 2 & 3.20 & & \\
\hline G I 3 & 3.34 & & \\
\hline G II 1 & 4.24 & \multirow{3}{*}{4.09} & \multirow{3}{*}{1.84} \\
\hline G II 2 & 4.13 & & \\
\hline G II 3 & 3.91 & & \\
\hline G III 1 & 4.18 & \multirow{3}{*}{4.34} & \multirow{3}{*}{1.95} \\
\hline G III 2 & 4.70 & & \\
\hline G III 3 & 4.15 & & \\
\hline G IV 1 & 4.24 & \multirow{3}{*}{4.43} & \multirow{3}{*}{1.99} \\
\hline G IV 2 & 4.90 & & \\
\hline G IV 3 & 4.15 & & \\
\hline G V 1 & 5.84 & \multirow{3}{*}{5.13} & \multirow{3}{*}{2.30} \\
\hline G V 2 & 4.20 & & \\
\hline GV 3 & 5.35 & & \\
\hline
\end{tabular}

where:

$$
f_{\text {of }}=\frac{1,5 \cdot F \cdot l}{b^{3}}
$$


$\mathrm{f}_{\mathrm{cf}}$ - theoretical bending strength;

$\mathrm{F}$ - load destroying the sample;

1 - distance between supports;

$\mathrm{b}$ - width of the cross-section of the bar.
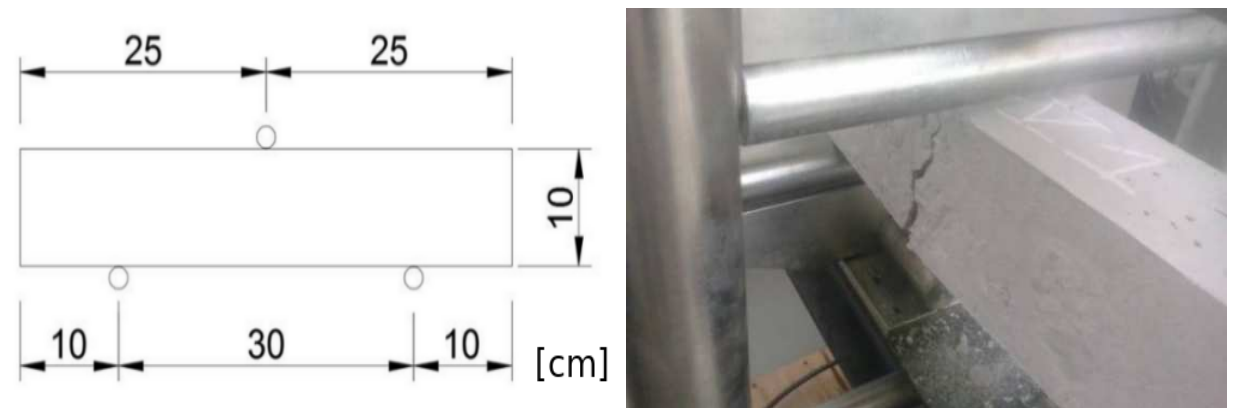

Fig. 3. From the left: sample support diagram and sample during the test

In the case of bending strength, the positive effect of the addition of microsilica on the strength parameters of the finished concrete is also confirmed.

\subsection{Water-tightness test}

Cubic samples with a size of $15 \times 15 \times 15 \mathrm{~cm}$. were tested for water-tightness. Each of the samples ripened at least 28 days. Before starting the test, all samples were dried to a constant mass in accordance with PN EN 12390-8:2011 [9]. The test was carried out on a standard apparatus for testing water-tightness of concrete. The water pressure exerted on the samples was lifted every 24 hours from 0.2 MPa to 1.2 MPa. The GV 1 sample began to leak immediately after the start of the study, therefore it is not taken into account when analyzing the test results. The remaining samples remained sealed until the maximum pressure was reached. Table 6 presents the results of the water-tightness test of the samples made. The soaking level was read at the sample breakthroughs (Fig. 4).

Table 6. Results of water tightness test

\begin{tabular}{|c|c|c|c|}
\hline \multirow{2}{*}{ Sample mark } & \multicolumn{2}{|c|}{ Soaking level } & \multirow{2}{*}{ Water-tightness class } \\
\cline { 2 - 2 } & {$[\mathrm{mm}]$} & Average value [mm] & \\
\hline G I 1 & 150 & \multirow{2}{*}{148.7} & W4 \\
\hline G I 2 & 146 & & \\
\hline G I 3 & 150 & \multirow{2}{*}{132.3} & W4 \\
\hline G II 1 & 144 & & \\
\hline G II 2 & 120 & 111.3 & W4 \\
\hline G II 3 & 133 & & \\
\hline G III 1 & 105 & & \\
\hline
\end{tabular}




\section{GRAINED CONCRETE}

\begin{tabular}{|c|c|c|c|}
\hline G III 2 & 121 & & \\
\cline { 1 - 2 } G III 3 & 108 & & \\
\hline G IV 1 & 95 & \multirow{2}{*}{90.7} & \multirow{2}{*}{ W4 } \\
\hline G IV 2 & 79 & & \\
\hline G IV 3 & 98 & \multirow{2}{*}{88.0} & W4 \\
\hline G V 1 & leak & & \\
\hline G V 2 & 93 & & \\
\hline
\end{tabular}

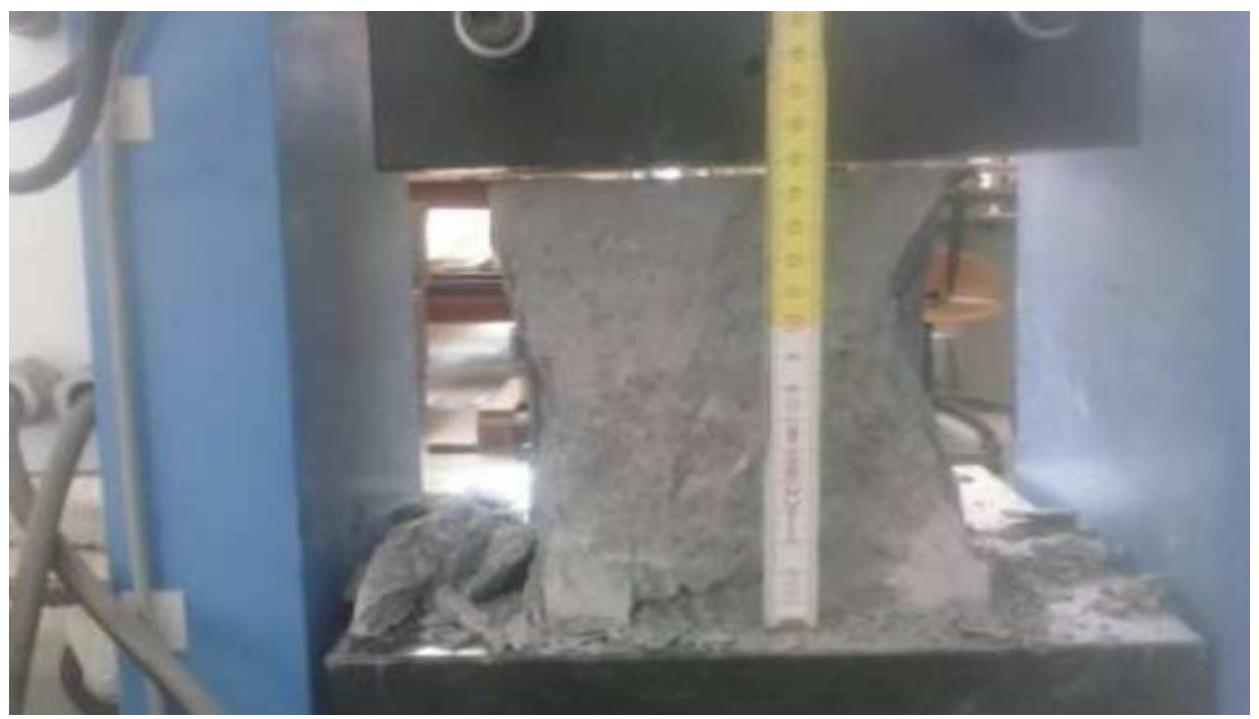

Fig. 4. Reading the soaking level at the turn of the sample

The study confirmed that with increasing the amount of microsilica in the concrete mix, the water resistance of the finished concrete increases. This is because the addition of microsilica reduces the porosity of the cement-binder matrix.

\subsection{Frost resistance test}

Cubes with a side of $10 \mathrm{~cm}$ were tested for frost resistance. The test consisted in assessing the behaviour of samples during 25 cycles of freezing and thawing in the temperature range from $+19^{\circ} \mathrm{C}$ to $-19^{\circ} \mathrm{C}$. The test involved 15 samples, 3 pieces with different silica fume content, $0 \%, 5 \%, 10 \%, 15 \%, 20 \%$ respectively. The entire test lasted 10 days. To assign the appropriate class of frost resistance after the end of 25 cycles, the samples were inspected for the resulting voids and cracks. It was found that cubes from mixture I (GI1, GI2, GI3) and cubes from mixture II (GII1, GII2, GII3) were completely destroyed. The percentage loss of 
mass (3.1) and the percentage loss of compressive strength (3.2) of the samples tested were calculated.

$$
\Delta G=\frac{G_{1}-G_{2}}{G_{1}} \cdot 100 \backslash \%
$$

where:

$\mathrm{G}_{1}$ - mean sample weight before freezing (saturated with water);

$\mathrm{G}_{2}$ - mean sample weight after freezing (saturated with water).

$$
\Delta R=\frac{R_{1}-R_{2}}{R_{1}} \cdot 100 \backslash \%
$$

where:

$\mathrm{R}_{1}$ - compressive strength of unfrozen samples, converted from strength of the cubes $15 \times 15 \times 15 \mathrm{~cm}$;

$\mathrm{R}_{2}$ - compressive strength of the cubes after the last cycle is thawing.

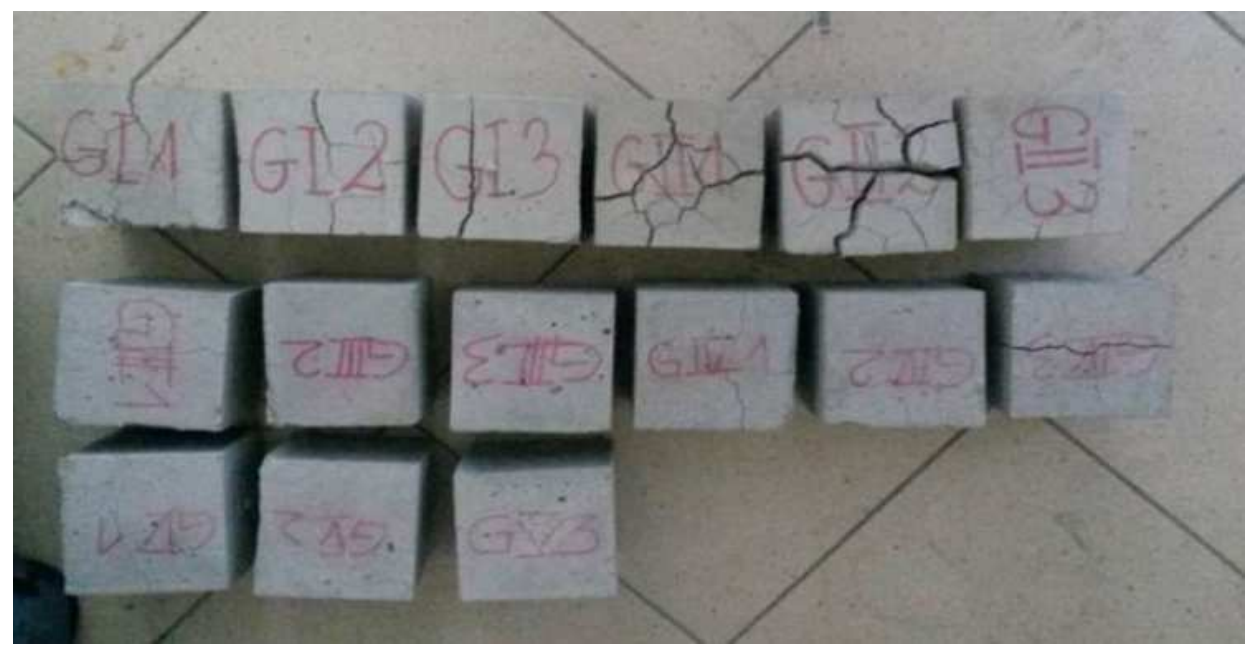

Fig. 5. Samples after frost resistance test ( 25 cycles)

The study showed that it is not possible to assign any class of frost resistance to any of the samples, as the strength drop compared to unfrozen samples is greater than $20 \%$. The test results are presented in the following Table 7. 
Table 7. Results of frost resistance test

\begin{tabular}{|c|c|c|c|c|c|c|c|c|c|}
\hline \multirow[t]{2}{*}{$\begin{array}{l}\text { Sample } \\
\text { mark }\end{array}$} & $\begin{array}{l}\text { Weight } \\
\text { before } \\
\text { freezing }\end{array}$ & G1 & $\begin{array}{l}\text { Weight } \\
\text { after } \\
\text { freezing }\end{array}$ & $\mathrm{G} 2$ & $\Delta \mathrm{G}$ & R1 & $\mathrm{R} 2$ & $\Delta \mathrm{R}$ & $\begin{array}{l}\text { Frost } \\
\text { resistance } \\
\text { class }\end{array}$ \\
\hline & \multicolumn{4}{|c|}{ [g] } & {$[\%]$} & \multicolumn{2}{|c|}{ [MPa] } & {$[\%]$} & \\
\hline G I 1 & 1872.0 & \multirow{3}{*}{1905.2} & 1764.9 & \multirow{3}{*}{1793.6} & \multirow{3}{*}{5.86} & \multirow{3}{*}{25.19} & \multirow{3}{*}{0} & \multirow{3}{*}{100} & \multirow{3}{*}{-} \\
\hline G I 2 & 1927.1 & & 1812.1 & & & & & & \\
\hline G I 3 & 1916.4 & & 1803.8 & & & & & & \\
\hline G II 1 & 1989.0 & \multirow{3}{*}{1944.5} & 1815.9 & \multirow{3}{*}{1807.5} & \multirow{3}{*}{7.04} & \multirow{3}{*}{34.25} & \multirow{3}{*}{0} & \multirow{3}{*}{100} & \multirow{3}{*}{ - } \\
\hline G II 2 & 1921.8 & & 1780.4 & & & & & & \\
\hline G II 3 & 1922.7 & & 1826.2 & & & & & & \\
\hline G III 1 & 2036.6 & \multirow{3}{*}{2018.6} & 2008.8 & \multirow{3}{*}{1975.9} & \multirow{3}{*}{2.11} & \multirow{3}{*}{39.07} & \multirow{3}{*}{28.32} & \multirow{3}{*}{27.51} & \multirow{3}{*}{ - } \\
\hline G III 2 & 1972.5 & & 1924.3 & & & & & & \\
\hline G III 3 & 2046.6 & & 1994.7 & & & & & & \\
\hline G IV 1 & 2012.2 & \multirow{3}{*}{1982.3} & 1960.5 & \multirow{3}{*}{1931.9} & \multirow{3}{*}{2.54} & \multirow{3}{*}{41.43} & \multirow{3}{*}{23.70} & \multirow{3}{*}{42.79} & \multirow{3}{*}{-} \\
\hline G IV 2 & 1956.6 & & 1905.9 & & & & & & \\
\hline G IV 3 & 1978.1 & & 1929.3 & & & & & & \\
\hline G V 1 & 2042.3 & \multirow{3}{*}{1995.5} & 2008.2 & \multirow{3}{*}{1961.4} & \multirow{3}{*}{1.71} & \multirow{3}{*}{39.98} & \multirow{3}{*}{30.58} & & \\
\hline G V 2 & 1978.0 & & 1942.5 & & & & & 23.51 & - \\
\hline G V 3 & 1966.2 & & 1933.6 & & & & & & \\
\hline
\end{tabular}

\section{CONCLUSIONS}

The tests have shown the beneficial effect of adding silica fume in the analyzed range to all parameters tested. The frost resistance test also confirmed the above trend, at the same time demonstrating that the addition of silica fume in itself can not be treated as an important factor increasing the resistance of fine-grained concrete to frost.

\section{REFERENCES}

1. Denisiewicz A., Kuczma M.: Two-scale modelling of reactive powder concrete. Part III: experimental tests and validation, Engineering Transactions, 63, 1, (2015), 55-76.

2. Kaszyńska M.: BWW: Możliwości, cechy, zastosowania, XVII Ogólnopolska Konferencja Warsztat Pracy Projektanta Konstrukcji, Ustroń, 2002. 
3. Ma J., Orgass F., Dehn F., Schmidt D., Tue N.V.: Comparative Investigations on Ultra-High Performance Concrete with and without Coarse Aggregates, International Symposium on Ultra High Performance Concrete, Kassel, Germany, 2004, pp. 205-212.

4. Richard P., Cheyrezy M., Composition of Reactive Powder Concretes, Cement and Concrete Research, 25 (1995), 1501-1511.

5. PN-EN 12350-2:2011 Badania mieszanki betonowej - Część 2: Badanie konsystencji metoda opadu stożka

6. PN-EN 12390-2:2011 Badania betonu - Część 2: Wykonywanie i pielęgnacja próbek do badań wytrzymałościowych

7. PN-EN 12390-3:2011 Badania betonu - Czesść 3: Wytrzymałość na ściskanie próbek do badań

8. PN-EN 12390-5:2011 Badania betonu - Część 5: Wytrzymatość na zginanie próbek do badań

9. PN-EN 12390-8:2011 Badania betonu - Część 8: Gtębokość penetracji wody pod ciśnieniem

10. PN-EN 206-1:2003 Beton - Część 1: Wymagania, właściwości, produkcja i zgodność

11. Śliwiński J., Zasady projektowania składu betonów wysokowartościowych, Cement wapno beton, 6 (2003).

\section{WPŁYW DODATKU MIKROKRZEMIONKI NA WYBRANE WŁAŚCIWOŚCI BETONU DROBNOZIARNISTEGO}

\section{Streszczenie}

W artykule zaprezentowano wyniki badań laboratoryjnych wybranych właściwości mechanicznych i fizycznych betonów drobnoziarnistych. Badania przeprowadzono na próbkach o różnym stopniu dodatku mikrokrzemionki. Dla zaprojektowanych mieszanek betonowych oraz wykonanych próbek wyznaczono klasę konsystencji, skurcz, wytrzymałość na ściskanie i zginanie, wodoszczelność i mrozoodporność.

Słowa kluczowe: pył krzemionkowy, beton drobnoziarnisty, badania laboratoryjne 